\title{
MANAGING FINANCIAL RISKS
}

\author{
R. POLAK'
}

\section{${ }^{\prime} V \breve{S} B-$ Technical University of Ostrava}

\begin{abstract}
Financial risks pose a threat for financial institutions and trade firms. Credit risk is mostly, and often rightly, considered as the most important factor. Nevertheless, it is important to be aware of the whole structure of potential financial risks. Accepting a risk is a condition for making profit. It today's dynamic reality, managing financial risk is a key objective of any successful company.
\end{abstract}

KEY WORDS: Financial risks, Transactions risks, Business environment risks, Relationships between risks

\section{INTRODUCTION}

Risk management is the process by which various risks faced by an enterprise are assessed in order to make the right business decision. Mostly the consideration is focused on credit risk which concerns both financial and non-financial firms. Nevertheless, it is necessary to be aware of the whole structure of financial risks.

\section{FINANCIAL RISKS}

\section{Credit risk}

The traditional view of credit risk is limited to the risk of the outright default of the counterparty. It is also important to place credit risk within a complex and usually interrelated web of other risks.

Risks may be subjective or objective. Subjective risks tend to have more impact to players in the game and they may be avoided. As such they often arise from specific transactions. Objective risks tend to be a product of the environment, can often affect the population in general and are more difficult to avoid without leaving the environment.

\section{Transactions risks}

Certain risks tend to arise from transactions or business relationships and often be managed within the relationship or avoided by ending the relationship. Many of these transactions risks tend to cause and be caused by other risks.

\section{Market risk}

In general usage, market risk refers to the risk that is created from any exchange of assets or liabilities. In special case of financial institutions, it is most commonly known as the risk that is created when an open position is held in derivative contract. Aside of derivatives exposure, market risk is often present when the value of financial and real assets is affected by volatility in the business environment.

\section{Liquidity risk}

Most firms face the almost daily task of apportioning assets and liabilities into short- and long-term classes in order to maximise returns. Longer-term investments are typically more profitable, but tie-up the firm's funds and may interfere with its ability to pay suppliers, 
employees or creditors. When a firm has more immediate claims than liquid assets (like cash, marketable securities, etc.) it may be forced to default on some or all of its obligations.

In the context of financial instruments, liquidity risk often usually refers to an inability to sell or trade the instrument because there may not be ready buyers for the instrument, even at the discount.

\section{Operating risk}

This is the risk of failure of internal processes or systems, and may include technological systems, business systems and organisational behaviour. Outside of financial institutions, operating risk may be associated with manufacturing, logistic, human resources, supply risk, etc. Each type of business may produce a unique set of operating risks.

\section{Business environment risks}

While the risks mentioned above emanate from either" the decisions that management makes or types of transactions in which they involve their firms, some risks are more a product of the business environment, but have little ability to influence the degree of risk.

\section{Interest rate risk}

In many businesses, interest risk is a double-edged sword. An increase in interest rates can affect both the cost of borrowed funds and the market for its product. If the cost of credit is a factor in determining whether to purchase a product today or wait until costs are lower, an increase in interest rates may result in a substantial decrease in revenues. Most consumer durable products, such as automobiles, appliances and furnishing fall into this category as would residential construction and related businesses. A host of credit disaster stories arise from interest rate-sensitive businesses inflicted with declining revenue as their variable-rate borrowing cost rise. Commercial banks are particularly prone to interest rate risk, which they may manage by matching rate-sensitive assets (like longer-term loans) with rate-sensitive liabilities (such as longer-term deposits) or by using interest rate derivatives.

\section{Foreign exchange risk}

Firms that operate in more than one currency, especially those that have earnings in a weaker currency and expenses in stronger currency are especially susceptible to this type of risk. It is not unusual for the gains made from an investment to be more than offset by an unfavourable movement in the currency of the investment.

Foreign exchange risk may arise from individual or serial transactions or longer-term decisions about international placement of operations. It tends to be associated with both interest rate and inflation risks, as these tend to correlate with foreign exchanged movement through market mechanisms. Other currency-related risks, such as the risk that currency cannot be freely converted into other major currencies (exchange risk) or that a host government will restrict repatriation of capital or dividends (blocked funds) are also associated with foreign exchange risk.

\section{Country risk}

Also referred to as sovereign risk, country risk is the risk that a country will itself default on its own debt. This also affects the credit worthiness of firms that operate in the country, and provides a good indication of inherent risk for companies operating in the country.

\section{Political risk}

This is the risk of political interference by national governments. Because individual firms have different amounts of exposure to this interference, it is a risk that is unique to each firm. A supplier of strategically important product or service with unique technology that a host country cannot access or copy would have much lower political risk than another foreign firm in less strategically important industry with local competitors and an easily copied product. 
While political risk is typically associated with unstable government in developing countries, it is also common in more developed countries, particularly in industries with longer-term investments. Home countries may also create political risk when they interfere in foreign operations. Regulatory risk is an associated risk. This is the risk of unforeseen changes in local regulatory regimes or the rules that they enforce.

\section{Force majeur risk}

These is always an unforeseeable risk that is often classified as an 'act of god', such as extreme weather. This risk is considered so rare as to be beyond the scope of normal contractual obligations, and is usually a 'way out' of completing a contract.

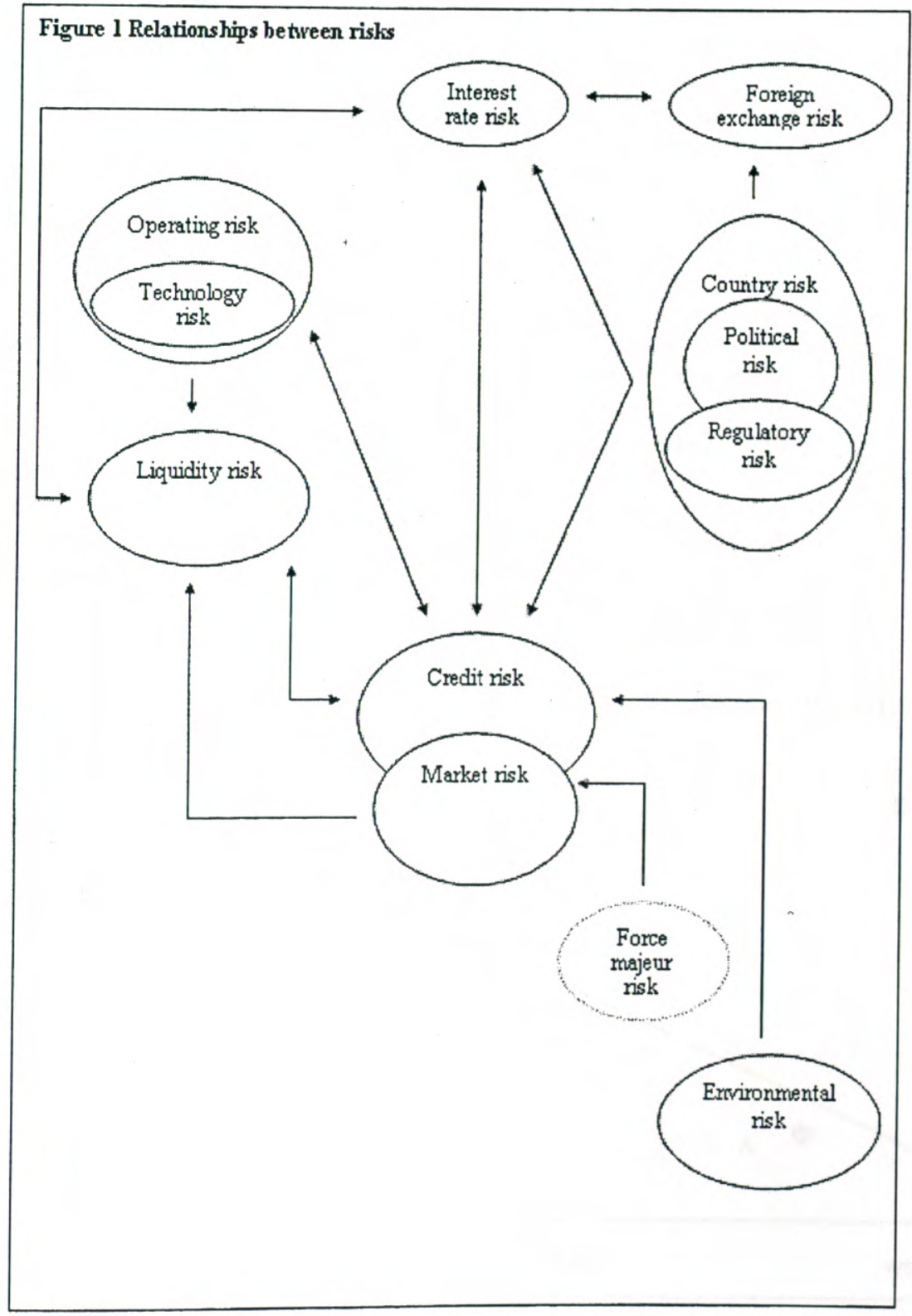




\section{Other risks}

In the preceding sections, some of the more obvious risks have been considered. Most industries will face at least one risk not considered above and yet important to that industry. For example, one brewing firm considers 'weather risk' to be one of its most important threats. A cool summer could significantly undermine sales. Analysts need to be able to spot the unique and unusual risk as well as the obvious ones.

\section{THE NEED FOR RISK UNDERWRITING}

A good example could be a leasing company. If a lessee defaults on a $€ 1$ million lease with 1 per cent margin and there is no recovery of the outstanding debt, a capital loss of $€ 1$ million occurs. This is the equivalent to the annual profit from 100 similar deals as well as the earnings that would have otherwise been achieved on the lost $€ 1$ million of capital. On the default of a lease of similar size with 5 per cent margin, the capital loss is the same, but is equivalent to the annual profit of only 20 similar deals. Thus a higher margin is justified on deals more likely to default. A lessor concentrating on return and ignoring risk is likely to fail through bad debts. One that has an over-cautious approach to risk is likely to fail through lack of new business.

A facility for a major bluechip public company will probably be low risk and that, together with the competitive pressure for the same business, will, in a perfect market, result in a low level of return for a lessor providing a lease to that company(see position $\mathrm{A}$ in the chart 2). A facility for a new company engaged in a speculative venture will be high risk and an appropriately high return will be necessary to justify the higher likelihood of default (see position B). The ideal position for lessors is position $\mathrm{C}$, where risk is low and return is high. Some of the highly-structured lease transactions in the market are attempts to achieve such a position. All should be seeking to avoid low-return, high-risk business(position D) Each facility does not have to have a perfect balance of risk and return, but a lease portfolio as a whole should provide a balance, with individual facilities mapped in a cluster around the upward sloping line in the figure 2 .

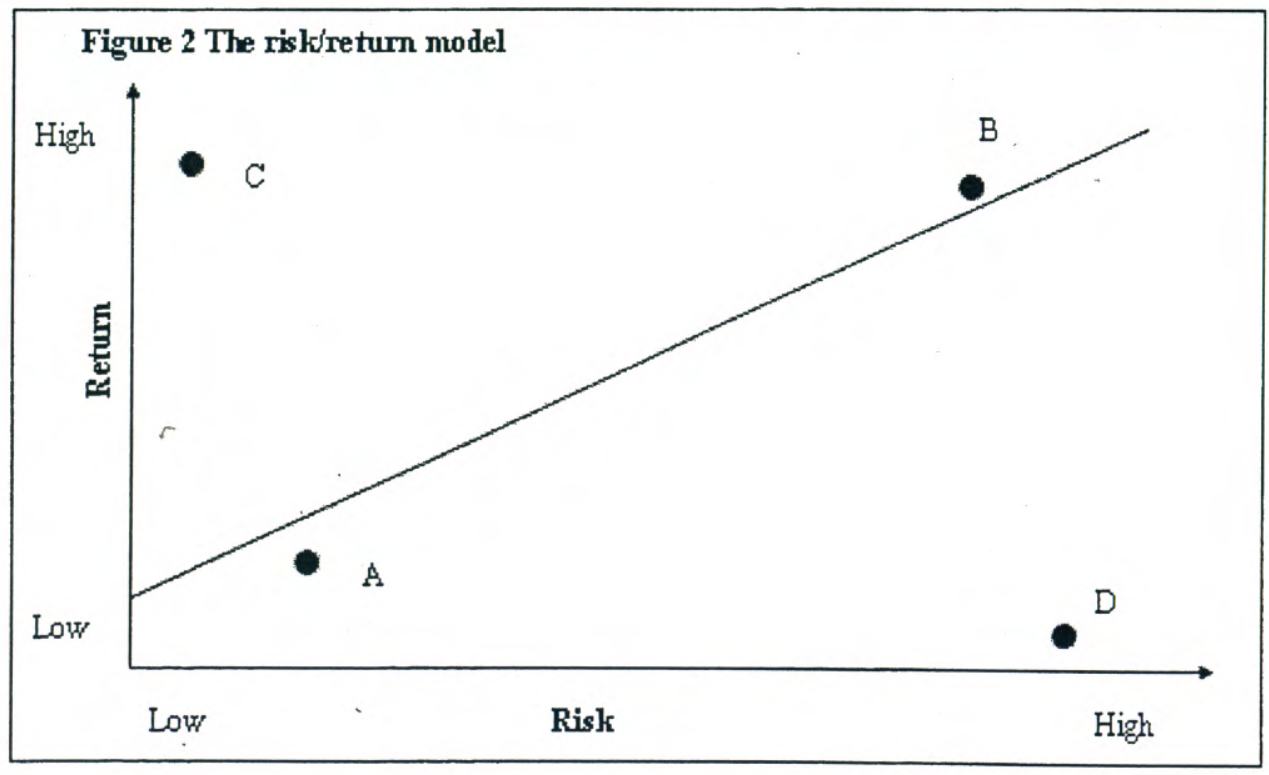




\section{CONCLUSION}

The business environment of the $21^{\text {st }}$ century is not the same as that last century. Our reality is changing so quickly that firms can no longer reasonably expect to be active in our complex markets without as many tools in the arsenal as possible to manage both risk and return. Different institutions necessarily have different approaches or focuses in monitoring and controlling risk. No single practice is universally effective. A clear conclusion is that effective risk management, in today's global environment, has increasingly become recognised as a core competency of the successful international enterprise.

\section{REFERENCES}

[1] Managing Credit Risk, Euromoney Books, 2003.

[2] The Practise of Risk Management, Euromoney Books, 1998.

[3] Leasing and Asset Finance, Euromoney Books, 2003

Reviewer: doc. Ing. Radim Lenort, Ph.D. 